\title{
Association of Hexachlorobenzene and Other Organochlorine Compounds with Anthropometric Measures at Birth
}

\author{
NÚRIA RIBAS-FITÓ, MARIA SALA, ESTHER CARDO, CARLOS MAZÓN, \\ M. EULÀlIA DE MUGA, ANTONI VERDÚ, ESTHER MARCO, JOAN O. GRIMALT, AND \\ JORDI SUNYER \\ Environmental and Respiratory Research Unit, Institut Municipal d'Investigació Mèdica, Barcelona, Spain \\ [N.R.-F., M.S., E.C., M.E.d.M., J.S.]; Primary Health Care Center, Flix, Tarragona, Spain [C.M.]; \\ Department of Paediatrics, Hospital de Móra d'Ebre, Tarragona, Spain [A.V.]; Department of \\ Environmental Chemistry, CID-CSIC, Barcelona, Spain [E.M., J.O.G.]
}

\begin{abstract}
ABST
The aim of the present study was to assess the association of
prenatal exposure to hexachlorobenzene (HCB) and other or-
ganochlorine compounds with anthropometric measures at birth.
A total of 98 mother-infant pairs $(83 \%$ of all children born in a
specific area polluted with HCB in the period $1997-1999)$ were
recruited after giving written consent. Levels of organochlorine
compounds were measured in 72 maternal serum samples at
delivery and in 70 cord serum samples. Of the organochlorines
measured in cord serum, median levels of HCB were higher than
for the other compounds (median of HCB $=1.13 \mathrm{ng} / \mathrm{mL}$, median
of dichlorodiphenyl dichloroethylene $=0.85 \mathrm{ng} / \mathrm{mL}$, and median
of total polychlorinated biphenyls $=0.27 \mathrm{ng} / \mathrm{mL})$. Premature
newborns had higher concentrations of HCB $[1.94 \mathrm{ng} / \mathrm{mL}$ among
prematures versus 1.10 among nonprematures $(p<0.10)]$ di-
chlorodiphenyl dichloroethylene $[2.40$ versus $0.80(p<0.05)]$,
and polychlorinated biphenyls in cord serum $[0.70$ versus $0.14(p$
$<0.10)]$. Those infants born with a small length for gestational
age had higher levels of HCB in cord serum than those with an
\end{abstract}
adequate length for gestational age $[1.64 \mathrm{ng} / \mathrm{mL}$ versus 1.00 $\mathrm{ng} / \mathrm{mL}(p<0.05)]$. In addition, HCB cord serum levels were negatively associated in a dose-response way with crown-heel length [for each doubling of the dose there was a decrease of 0.46 $(\mathrm{SE}=0.22) \mathrm{cm}]$ after adjusting for smoking, gestational age, and other organochlorine compounds. The associations of dichlorodiphenyl dichloroethylene and polychlorinated biphenyls with length were not significant. The results did not vary when stratified for prematurity. These data suggest that HCB reduces intrauterine physical linear growth. (Pediatr Res 52: 163-167, 2002)
HCB, hexachlorobenzene

\section{Abbreviations}
p,p'-DDE, dichlorodiphenyl dichloroethylene
$\boldsymbol{\beta}$-HCH, $\beta$-hexachlorocyclohexane
PCB, polychlorinated biphenyls

Whether exposure to persistent organochlorine pollutants has an adverse effect on children's health is a matter of worldwide concern (1). Production and intensive use of organochlorine chemicals like HCB in agriculture and industrial processes in the past have led to a widespread contamination of the environment. At present, HCB is still formed as a byproduct during the manufacture of some chlorinated solvents. The main intake of organochlorine compounds in humans is through diet and, in unusual circumstances, by inhalation (2).

Received January 20, 2001; accepted October 31, 2001.

Correspondence: Jordi Sunyer, M.D., Ph.D., Environmental and Respiratory Research Unit, Institut Municipal d'Investigació Mèdica (IMIM), C. del Doctor Aiguader, 80, E-08003-Barcelona, Spain; e-mail: jsunyer@imim.es

Supported, in part, by grants from "Fundació La Caixa" 97/009.00, the Spanish Ministry of Health (FIS-97/1102), and Generalitat de Catalunya-CIRIT 1999SGR 00241.

DOI: 10.1023/01.PDR.0000023171.89966.8B
Newborns are exposed across the placenta and by breastfeeding $(3,4)$.

Exposure to some organochlorine compounds, such as PCB, has been associated with fetal growth alterations such as a decrease of birth weight and birth length (5). Specific effects of HCB on birth weight have been also found in animals (6), but little information is available about the effects on humans.

In a rural village of 5000 inhabitants located in the vicinity of an electrochemical factory (Flix, Catalonia, Spain), unusually high atmospheric levels of HCB were detected. Adult inhabitants studied in 1994 had the highest serum HCB levels ever found (7), and levels of HCB in the cord serum of newborns from this population are among the highest ever reported (8). A general population birth cohort was set up in this area to assess the effects of prenatal and postnatal HCB exposure on growth and neurologic development of infants. 
The aim of the present study was to assess the association of prenatal exposure to hexachlorobenzene and other organochlorine compounds with anthropometric measurements.

\section{SUBJECTS AND METHODS}

Subjects. All children born in the main hospital of the study area during the period March 1997 to December 1999 were selected. The study area included the village of Flix and all other towns of the same administrative health area $(12,000$ inhabitants). A total of 110 children were born in this hospital (93\% of all children born in the study area). The children had no congenital anomalies or diseases. Two non-Caucasian infants and two twins were excluded. The mothers of 98 infants (93\% of the eligible cases, $83 \%$ of all children born in the area) gave written consent. This study was approved by the ethical committee of the Institut Municipal d'Investigació Mèdica.

Exposure measures. Organochlorine compounds were measured in 72 maternal serum samples at delivery and in 70 cord serum samples. From the remaining mothers and newborns, no information was available due to the small volume of the obtained samples. Serum samples were stored at $-40^{\circ} \mathrm{C}$ until analysis. Organochlorine compounds in sera were analyzed by gas chromatography (GC) with electron capture detection and GC coupled to chemical ionization negative-ion mass spectrometry. All the analyses were carried out in the Department of Environmental Chemistry (CID-CSIC). Details of the methodology have been reported elsewhere (9). We present results for the most prevalent compounds found in sera samples, HCB, p,p'-DDE, and PCB, which we present as the summation of the individual congeners $28,52,101,118,138,153$, and 180 , and $\mathrm{HCH}$. Because the sum of PCB 118, 138, 153, and 180 represented $91 \%$ and $98 \%$ of total PCBs in cord serum and in maternal serum, respectively, we also provide results for these four congeners. Detection limits for $\mathrm{HCB}, \beta-\mathrm{HCH}$, and $\mathrm{p}, \mathrm{p}^{\prime}-$ DDE were $0.03,0.15$, and 0.09 , respectively, and for the individual PCB congeners 28, 52, 101, 118, 138, 153, and 180 were $0.17,0.15,0.09,0.11,0.15,0.12$, and $0.10 \mathrm{ng} / \mathrm{mL}$, respectively. A value of $0.01 \mathrm{ng} / \mathrm{mL}$ was given for the nondetectable levels and a value of $0.05 \mathrm{ng} / \mathrm{mL}$ for those detectable but not quantifiable.

The between-assay coefficient of variation for the assays was $6.4 \%$ for $\mathrm{HCB}, 11.5 \%$ for $\beta$-HCH, $8.6 \%$ for $\mathrm{p}, \mathrm{p}$-DDE, and $9.5 \%, 7.1 \%, 6 \%, 11 \%, 8.4 \%, 7.1 \%$, and $8.9 \%$ for the individual PCB congeners $28,52,101,118,138,153$, and 180 , respectively.

Outcome measures. Anthropometric measures at birth were obtained from the hospital delivery record. All measures were taken in the delivery room with the same device. Gestational age was based on the mother's report of her last menstrual period.

The outcome variables were birth weight (in grams), crownheel length (in centimeters), head circumference (in centimeters), prematurity ( $\leq 37 \mathrm{wk})$, small weight for gestational age (defined as birth weight below the 10th percentile for gestational age) and small length for gestational age (defined as birth length below the 10th percentile for gestational age) (10).
Other variables. Information on socioeconomic background, maternal history, parity, gender, and fetal exposure to alcohol and cigarette smoking was obtained with a questionnaire that was administered in person. Active prenatal smoking was defined as smoking at least one cigarette per day during the entire gestation period based on self-report. Passive smoking was defined as exposure to any smoker either at home or at work.

Statistics and data analysis. Cord serum organochlorine levels were normalized by base 2 logarithmic transformation because their distribution was skewed to the right. Two sets of multiple linear regression analyses were used to study the associations between prenatal organochlorine exposure on birth weight, crown-heel length, and head circumference. In the first set of models, the dependent variable (either birth weight, crown-heel length, or head circumference) was examined in relation to level of organochlorines and other variables. Both continuous and categorized levels of HCB, p,p'-DDE, $\beta-\mathrm{HCH}$, and total $\mathrm{PCB}$, were used in the regression analyses. Models for the most frequent PCB congeners $(118,138,153$, and 180) were also fitted. PCB congeners were only analyzed as categorical variables given the high proportion of nonquantifiable values. In the second set of models, the dependent variable (organochlorine level) was examined in relation to prematurity, small weight, length for gestational age, and other variables. Potential confounding variables, such as sex, maternal tobacco and/or alcohol consumption during pregnancy, gestational diabetes, parity, maternal height, weight and body mass index, maternal and paternal education, and maternal and paternal social class, were considered for inclusion in the regression based on the literature. Variables were included in the final regression model if their association with the outcome had a $p$ value $<0.2$. All statistical analyses were conducted with the SPSS and STATA statistical software packages (SPSS Inc., Chicago, IL, U.S.A.). A $p$ value $<0.05$ was considered statistically significant.

\section{RESULTS}

There were no significant differences in the outcome variables or covariates between those mother-infant pairs with biologic samples and those without [means (SE) and percentages among those mother-infant pairs with samples: birth weight $=3244.6(488.78) \mathrm{g}$; crown-heel length $=49.4(2.19)$ $\mathrm{cm}$; head circumference $=34.4(1.65) \mathrm{cm}$; premature $=6 \%$; small weight for gestational age $=10 \%$; and small length for gestational age $=17 \%]$. The highest organochlorine levels were found for HCB followed by $p, p^{\prime}-\mathrm{DDE}, \beta-\mathrm{HCH}$, and, finally, by the sum of seven PCB congeners both in cord serum (Table 1) and in maternal serum (data not shown). Levels of $\mathrm{HCB}$ and total PCB in cord serum were quantified in $100 \%$ of the samples, and levels of p,p'-DDE in $97 \%$. Among the PCB congeners, PCB 118 was not quantifiable in any of the samples. HCB cord serum levels were similar in children whose mother were smokers (median $=1.03 \mathrm{ng} / \mathrm{mL}, n=23$ ) and nonsmokers $(1.21 \mathrm{ng} / \mathrm{mL}, n=47)(p=0.3)$, as were $\mathrm{p}, \mathrm{p}$-DDE levels $(0.67$ and 0.92 , respectively) and total PCB (0.23 and 0.31 , respec- 
Table 1. Levels of organochlorine compounds in cord serum $(n g / m L)(n=70)$

\begin{tabular}{|c|c|c|c|c|c|c|c|}
\hline & $\begin{array}{c}\text { Detectable } \\
\text { levels } \\
(\%)\end{array}$ & $\begin{array}{c}\text { Quantifiable } \\
\text { levels } \\
(\%)\end{array}$ & \multicolumn{5}{|c|}{ Percentiles } \\
\hline $\mathrm{HCB}$ & 100 & 100 & 0.33 & 0.79 & 1.13 & 1.72 & 3.14 \\
\hline$\beta-\mathrm{HCH}$ & 87 & 69 & 0.01 & 0.05 & 0.54 & 1.08 & 2.53 \\
\hline PCB138 & 91 & 27 & 0.01 & 0.05 & 0.05 & 0.19 & 1.01 \\
\hline PCB180 & 90 & 23 & 0.01 & 0.05 & 0.05 & 0.05 & 0.65 \\
\hline All PCB & 100 & 100 & 0.11 & 0.19 & 0.27 & 0.58 & 2.03 \\
\hline
\end{tabular}

tively). The results did not vary when nonsmokers were categorized as exposed or nonexposed to passive smoking.

$\mathrm{HCB}$ cord serum levels were inversely associated with crown-heel length, even adjusting for smoking and the other potential confounding variables such as parents' education (Table 2). The associations had a dose-response relationship (decreased length with increasing HCB tertiles) and were statistically significant for the highest level of exposure. When maternal serum levels at delivery were analyzed instead of cord serum levels, an inverse association was also observed [coefficient (SE) for the third tertile of maternal $\mathrm{HCB}$ exposure = $1.02(0.48) \mathrm{cm}(p=0.04)]$.

Neither birth weight nor head circumference (data not shown) were associated with HCB. Inverse associations with

Table 2. Coefficients (SE) from multivariate models of birth weight and crown-heel length

\begin{tabular}{lcc}
\hline & $\begin{array}{c}\text { Birth weight } \\
(\mathrm{g})\end{array}$ & $\begin{array}{c}\text { Crown-heel length } \\
(\mathrm{cm})\end{array}$ \\
\hline Reference $\dagger$ & $3220.6(59.9)$ & $50.08(0.51)$ \\
$\mathrm{HCB} 0.9-1.48 \mathrm{ng} / \mathrm{mL}$ & $-66.28(109.1)$ & $-0.70(0.53)$ \\
$\mathrm{HCB}>1.48 \mathrm{ng} / \mathrm{mL}$ & $29.09(114.9)$ & $-1.08(0.53)^{*}$ \\
$\mathrm{Sex}$, boys & $122.1(93.5)$ & $0.87(0.42)^{*}$ \\
Cigarettes/day & $-21.7(9.6)^{*}$ & $-0.10(0.04)^{*}$ \\
Alcohol intake, yes & - & $-1.28(0.59)^{*}$ \\
Gestational age $(\mathrm{wk})$ & $206.9(30.2)^{*}$ & $0.78(0.13)^{*}$ \\
Maternal age $(\mathrm{y})$ & $15.9(9.4)$ & - \\
Maternal body mass index $\left(\mathrm{kg} / \mathrm{m}^{2}\right)$ & $24.7(13.3)$ & $0.12(0.06)^{*}$ \\
Gestational diabetes, yes & - & $1.97(0.70)^{*}$ \\
Parents' education, & - & $-0.27(0.49)$ \\
$\quad$ Low in one of them & & $-0.93(0.52)$ \\
$\quad$ Low in both of them & & \\
\hline
\end{tabular}

Each column is a different multivariate model (birth weight and crown-heel length). The covariates included in regression models were levels of HCB in cord serum (three categories: in tertiles), sex (two categories), smoking in pregnancy (continuous), alcohol intake during pregnancy (two categories), gestational age (continuous), maternal age (continuous), maternal body mass index (continuous), gestational diabetes (two categories), and parent's education (three categories).

$\dagger$ Newborns with a HCB level $<0.09 \mathrm{ng} / \mathrm{mL}$ in cord serum, female, nonexposed to alcohol or tobacco during gestation, born at $39.7 \mathrm{wk}$, whose mothers were $30.7 \mathrm{y}$ old and had a body mass index of $23.7 \mathrm{~kg} / \mathrm{m}^{2}$, did not have a gestational diabetes and neither the paternal nor the maternal education were low (up to primary school). Values for each variable $(\beta)$ are change (per unit increase if continuous or category change if categorical) in the reference value; i.e. a newborn who differed to the reference in the HCB levels $(1.26 \mathrm{ng} / \mathrm{mL})$ and the sex (male) would have a predicted birth weight of 3220.6-66.28+ $122.1 \mathrm{~g}$ and a crown-heel length of $50.08-0.70+0.87 \mathrm{~cm}$.

$* p<0.05$.

— Variables not included due to $p>0.20$. crown-heel length were also found for the other organochlorine compounds but these were not statistically significant (Table 3). The association of HCB with length was not modified after adjusting for the other organochlorine compounds. Smoking was negatively associated with birth weight and crown-heel length (Table 2). No interaction between HCB levels and maternal smoking was found.

Newborns with a small length for gestational age had higher levels of all organochlorine compounds, but were only statistically significantly different for HCB (Table 4). No differences in organochlorine compounds were encountered between those newborns with and without small weight for gestational age. Premature newborns showed higher concentrations of HCB, $\mathrm{p}, \mathrm{p}$-DDE, $\beta-\mathrm{HCH}$, and total PCB at birth than those born at term, being only significantly different for $p, p^{\prime}-D D E$. When the above analyses were repeated after excluding prematures, HCB cord serum levels were also associated with a decrease in crown-heel length, either in a continuous [for each doubling of a dose there was a decrease of $-0.53(0.24) \mathrm{cm}]$ or in a categorical way [coefficients (SE) $=-0.68(0.54)$ and -1.10 $(0.55)$ for the second and third tertile, respectively]. Moreover, those infants born with a small length for gestational age had higher concentrations of HCB in cord serum than those with an adequate length for gestational age [geometric mean $=1.87$

Table 3. Effects (coefficient and SE) of other organochlorine compounds in cord serum on birth weight and crown-heel length

\begin{tabular}{lcc}
\hline & $\begin{array}{c}\text { Birth Weight } \\
(\mathrm{g}) \dagger\end{array}$ & $\begin{array}{c}\text { Crown-heel Length } \\
(\mathrm{cm}) \dagger\end{array}$ \\
\hline $\mathrm{HCB}(\mathrm{ng} / \mathrm{mL}) \#$ & $19.8(50.9)$ & $-0.48(0.23)^{*}$ \\
$\mathrm{p}, \mathrm{p}^{\prime}-\mathrm{DDE}(\mathrm{ng} / \mathrm{mL}) \#$ & $-16.8(37.8)$ & $-0.20(0.15)$ \\
$\beta-\mathrm{HCH}(\mathrm{ng} / \mathrm{mL}) \#$ & $17.5(17.6)$ & $-0.02(0.08)$ \\
$\mathrm{All} \mathrm{PCB}(\mathrm{ng} / \mathrm{mL}) \#$ & $-5.6(36.1)$ & $-0.12(0.16)$ \\
Quantifiable levels of PCB138§ & $-41.4(97.6)$ & $-0.46(0.46)$ \\
Quantifiable levels of PCB180§ & $118.7(104.2)$ & $-0.49(0.52)$ \\
Quantifiable levels of PCB153§ & $-50.1(107.9)$ & $-0.52(0.48)$ \\
Detectable levels of PCB118 & $-18.2(86.4)$ & $-0.20(0.40)$ \\
\hline
\end{tabular}

Each coefficient derives from a different multivariate model. \# Each unit change represents a doubling of the concentration in $\mathrm{ng} / \mathrm{mL}$ of each organochlorine compound in cord serum. § Levels of each specific PCB $>0.05$ $\mathrm{ng} / \mathrm{mL}$ in cord serum. ๆ Levels of PCB118 $>0.01 \mathrm{ng} / \mathrm{mL}$ in cord serum.

$* p<0.05$.

$\dagger$ Adjusted for sex, gestational age, number of cigarettes per day during gestation, maternal body mass index, and maternal age.

$\$$ Adjusted for sex, gestational age, number of cigarettes per day and alcohol intake during gestation, maternal body mass index, parents' education and gestational diabetes. 
Table 4. Geometric mean of organochlorine compounds in cord serum according to prematurity and small weight and length for gestational age

\begin{tabular}{|c|c|c|c|c|c|c|}
\hline & \multicolumn{2}{|c|}{ Prematurity ( $\leq 37 \mathrm{wk}$ ) } & \multicolumn{2}{|c|}{$\begin{array}{l}\text { Small weight for } \\
\text { gestational age } \dagger\end{array}$} & \multicolumn{2}{|c|}{$\begin{array}{c}\text { Small length for gestational } \\
\text { age }\end{array}$} \\
\hline & $\begin{array}{c}\text { Yes } \\
n=4\end{array}$ & $\begin{array}{l}\text { No } \\
n=66\end{array}$ & $\begin{array}{c}\text { Yes } \\
n=7\end{array}$ & $\begin{array}{c}\text { No } \\
n=63\end{array}$ & $\begin{array}{c}\text { Yes } \\
n=12\end{array}$ & $\begin{array}{l}\text { No } \\
n=58\end{array}$ \\
\hline HCB (ng/mL) & 1.94 & $1.10^{* *}$ & 1.10 & 1.10 & 1.64 & $1.00 *$ \\
\hline $\mathrm{p}, \mathrm{p}^{\prime}-\mathrm{DDE}(\mathrm{ng} / \mathrm{mL})$ & 2.40 & $0.80^{*}$ & 0.47 & 0.77 & 0.88 & 0.65 \\
\hline$\beta$-HCH (ng/mL) & 0.55 & 0.26 & 0.15 & 0.32 & 0.54 & 0.23 \\
\hline All PCB (ng/mL) & 0.70 & $0.34 * *$ & 0.28 & 0.37 & 0.51 & 0.32 \\
\hline
\end{tabular}

Each coefficient derives from a different multivariate model.

$* p<0.05 ; * * p<0.10$.

$\dagger$ Adjusted for sex and number of cigarettes per day.

$\ddagger$ Adjusted for sex, number of cigarettes per day during gestation, and maternal body mass index.

$\mathrm{ng} / \mathrm{mL}$ versus $\mathrm{gm}=0.96 \mathrm{ng} / \mathrm{mL}(p=0.01)]$. Findings for maternal HCB (instead of cord serum HCB) were similar.

\section{DISCUSSION}

The main finding of the present study was that higher HCB levels in maternal and in cord serum were negatively associated with crown-heel length but not with birth weight. This association was not explained by prematurity or gestational age, although premature newborns had higher levels of HCB. These associations were independent of the role of maternal smoking during pregnancy. Most of the studies of prenatal organochlorine exposure in relation to size at birth have only assessed the effects on birth weight.

In utero exposure to PCBs was related to an increased risk of having an infant with low birth weight in a number of studies $(5,11-14)$, but not in studies conducted in North Carolina (15) and in Finland (16). Only one study reported an association between prenatal exposure to HCB and lower birth weights of female infants (17) and a recent large study reported a strong relation between $\mathrm{p}, \mathrm{p}^{\prime}-\mathrm{DDE}$ and lower birth weight (18). In our study, no effects on birth weight could be observed for any of the organochlorine compounds but levels of p,p'DDE were much lower than in the previous study and levels of PCB in the cord serum of our newborns were lower than those reported recently in other sites (19).

Among the studies reporting effects of prenatal exposure to PCB on birth length $(5,14)$, only the study in Taiwan, with higher levels of PCB and other compounds, found a statistically significant association with birth length. We similarly found no association between PCB and length but we observed a significant association with HCB. It is important to note that skeletal growth, as reflected by body length, may have considerable prognostic value for subsequent growth and development of the newborn. Morris et al. (20) found a strong direct association between birth length on both the psychomotor development and attained length at 12 mo.

Premature newborns had higher levels of organochlorines, particularly of p,p'-DDE. Previous results in the literature are quite controversial. Longnecker et al. (18) have recently found that maternal serum concentration of p,p'-DDE was associated with increased odds of premature births, but in another study, with lower levels of p,p'-DDE in women, a lack of an association between $\mathrm{p}, \mathrm{p}^{\prime}-\mathrm{DDE}$ and preterm delivery was found (21).
Two human population-based studies had previously found an association with PCB levels $(12,22)$. The role of organochlorines in prematurity could be of a different nature than the mechanisms underlying the linear growth delay, and should be reassessed in larger populations.

A recent study in Germany has shown that $\mathrm{HCB}$ and $\mathrm{PCB}$ levels at birth were higher in smokers' newborns than in nonsmokers' newborns (23). We did not find that levels of HCB (or other organochlorine compounds) were higher in smokers' children, and we observed that the association between $\mathrm{HCB}$ and length was independent of the smoking effect.

The present study was able to find significant results despite its small size. This might be explained by the strength of the associations. This cohort is representative of the infants born in an HCB-polluted area. Participation rates in this study were high and selection bias is unlikely. These data suggest that HCB reduces intrauterine physical linear growth.

Acknowledgments. The authors thank all the participants for their generous collaboration and all personnel of the pediatric department of the Hospital de Móra d'Ebre and Primary Health Care Center of Flix for their help in obtaining the data. We also thank Dave MacFarlane for his help in editing.

\section{REFERENCES}

1. Ross PS, Vos JG, Birnbaum LS, Osterhaus ADME 2000 PCBs are a health risk for humans and wildlife. Science 289:1878-1879

2. Sala M, Sunyer J, Otero R, Santiago-Silva M, Camps C, Grimalt JO 1999 Organochlorine compound concentration in the serum of inhabitants living near an electrochemical factory. Occup Environ Med 56:152-158

3. Huisman M, Koopman-Esseboom C, Fidler V, Hadders-Algra M, van der Paauw CG, Tuinstra LG, Weisglas-Kuperus N, Sauer PJ, Touwen BC, Boersma ER 1995 Perinatal exposure to polychlorinated biphenyls and dioxins and its effect on neonatal neurological development. Early Hum Dev 41:111-127

4. Rhainds M, Levallois P, Ayotte P 1999 Lead, mercury, and organochlorine compound levels in cord blood in Québec, Canada. Arch Environ Health 54:40-47

5. Rogan WJ, Gladen BC, Hung KL, Koong SL, Shih LY, Taylor JS, Wu YC, Yang D, Ragan NB, Hsu CC 1988 Congenital poisoning by polychlorinated biphenyls and their contaminants in Taiwan. Science 241:334-336

6. Newhook R, Dormer W 1996 International Programme on Chemical Safety: Environmental Health Criteria for Hexachlorobenzene. World Health Organization, Geneva, pp 82-86

7. Sala M, Sunyer J, Otero R, Santiago-Silva M, Ozalla D, Herrero C, To-Figueras J, Kogevinas M, Anto JM, Camps C, Grimalt J 1999 Health effects of chronic high exposure to hexachlorobenzene in a general population sample. Arch Environ Health 54:102-109

8. Sala M, Ribas-Fitó N, Cardo E, de Muga ME, Marco E, Mazón C, Verdú A, Grimalt JO, Sunyer J 2001 Levels of hexachlorobenzene and other organochlorine compounds in cord blood: exposure across palcenta. Chemosphere 43:895-901 
9. To-Figueras J, Sala M, Otero R, Barrot C, Santiago-Silva M, Rodamilans M, Herrero C, Grimalt J, Sunyer J 1997 Metabolism of hexachlorobenzene in humans: association between serum levels and urinary metabolites in a highly exposed population. Environ Health Perspect 105:78-83

10. Jiménez R, Figueras J, Botet F 1995 Neonatología. Procedimientos diagnósticos y terapéuticos. Ed Espaxs, Barcelona, pp 36-40

11. Taylor PR, Stelma JM, Lawrence CE 1989 The relation of polychlorinated biphenyls to birth weight and gestational age in the offspring of occupationally exposed mothers. Am J Epidemiol 129:395-406

12. Fein GG, Jacobson JL, Jacobson SW, Schwartz PM, Dowler JD 1984 Prenatal exposure to polychlorinated biphenyls: effects on birth size and gestational age. J Pediatr 105:315-320

13. Rylander L, Strömberg U, Dyremark E, Östman C, Nilsson-Ehle P, Hagmar L 1998 Polychlorinated biphenyls in blood plasma among Swedish female fish consumers in relation to low birth weight. Am J Epidemiol 147:493-502

14. Patandin S, Koopman-Esseboom C, De Ridder MA, Weisglas-Kuperus N, Sauer PJ 1998 Effects of environmental exposure to polychlorinated biphenyls and dioxins on birth size and growth in Dutch children. Pediatr Res 44:538-545

15. Rogan WJ, Gladen BC, McKinney JD, Carreras N, Hardy P, Thullen J, Tinglestad J, Tully M 1986 Neonatal effects of trasnplancental exposure to PCBs and DDE. J Pediatr 109:335-341

16. Vartiainen T, Jaakkola JJ, Saarikoski S, Tuomisto J 1998 Birth weight and sex of children and the correlation to the body burden of PCDDs/PCDFs and PCBs of the mother. Environ Health Perspect 106:61-66
17. Schade G, Heinzow B 1998 Organochlorine pesticides and polychlorinated biphenyls in human milk of mothers living in northern Germany: current extent of contamination, time trend from 1986 to 1997 and factors that influence the levels of contamination. Sci Total Environ 215:31-39

18. Longnecker MP, Klebanoff MA, Zhou H, Brock JW 2001 Association between maternal serum concentration on the DDT metabolite DDE and preterm and smallfor-gestational-age babies at birth. Lancet 358:110-114

19. Korrick SA, Altshul LM, Tolbert PE, Burse VW, Needham LL, Monson RR 2000 Measurement of PCBs DDE, and hexachlorobenzene in cord blood from infants born in towns adjacent to a PCB-contaminated waste site. J Expo Anal Environ Epidemiol 10:743-754

20. Morris SS, Victora CG, Barros FC, Halpern R, Menezes AM, Cesar JA, Horta BL, Tomasi E 1998 Length and ponderal index at birth: associations with mortality, hospitalizations, development and post-natal growth in Brazilian infants. Int J Epidemiol 27:242-247

21. Berkowitz GS, Lapinski RH, Wolff MS 1996 The role of DDE and polychlorinated biphenyl levels in preterm birth. Arch Environ Contam Toxicol 30:139-141

22. Wasserman M, Ron M, Bercovici B, Wassermann D, Cucos S, Pines A 1982 Premature delivery and organochlorine compounds: polychlorinated biphenyls and some organochlorine insecticides. Environ Res 28:106-112

23. Lackmann GM, Angerer J, Tollner U 2000 Parental smoking and neonatal serum levels of polychlorinated biphenyls and hexachlorobenzene. Pediatr Res 47: $598-601$ 